\section{SCREENING FOR INHIBITORS OF AVIAN MYELOBLASTOSIS VIRUS REVERSE TRANSCRIPTASE AND EFFECT ON THE REPLICATION OF AIDS-VIRUS}

\section{Yoshio INOUYE*, YUKINORI TAKE and Shoshiro NaKamura}

Institute of Pharmaceutical Sciences, Hiroshima University School of Medicine, 1-2-3 Kasumi, Minami-ku, Hiroshima 734, Japan

\section{Hideki Nakashima and NaOki Yamamoto}

\author{
Department of Virology and Parasitology, \\ Yamaguchi University School of Medicine, \\ 1144 Kogushi, Ube, Yamaguchi 755, Japan

\section{Hiroshi KaWaguchi}
Bristol-Myers Research Institute, Ltd., Tokyo Research Center, 2-9-3 Shimo-meguro, Meguro-ku, Tokyo 153, Japan

(Received for publication August 4, 1986)

Reverse transcriptase plays an important role in the natural cycle of retroviruses including human immunodeficiency virus (HIV), a causative agent of aquired immune deficiency syndrome (AIDS) and AIDS related complex (ARC), especially in the early stage of integration of viral genomes into cellular $\mathrm{DNA}^{1,2)}$. Since HIV features not only reverse transcription but also cytopathic effect on $\mathrm{OKT}_{4}^{+} \mathrm{T}$ cells $^{3)}$, natural hosts of the virus, it seems acceptable that the inhibitors of this enzyme are of potential therapeutic use against AIDS and
ARC. HPA 23 $3^{4)}$ and suramin ${ }^{5)}$, both the active inhibitors of reverse transcriptases of various species origin, have been applied to AIDS or ARC patients. Recently, the clinical application of azidothymidine was reported ${ }^{\beta)}$. The reverse transcriptase catalyzed chain elongation of DNA was presumably terminated by the incorporation of azidothymidine triphosphate formed by cellular kinases.

The inhibition of reverse transcriptase by antibiotics such as rifamycin derivatives ${ }^{7)}$, adriamycin $^{8)}$, daunomycin ${ }^{8)}$, distamycin $A^{97}$, sakyomicin $\mathrm{A}^{10)}$ and streptonigrin ${ }^{1,12)}$ has been reported. Most of these works were, however, carried out many years ago and under different assay conditions. In order to revaluate systematically these observations and to extend them to the wide range of antibiotics, we have been conducting mass survey for inhibitors of reverse transcriptase. According to the recent observations ${ }^{137}$, it is suggested that the properties of reverse transcriptases of various species origin are closely related. Therefore, we used commercially available avian myeloblastosis virus reverse transcriptase as a model enzyme. For the in vitro assay of viral replication, the cytotoxicity of a test sample should be as low as enough not to mask the effect on viral replication. For this purpose, antibiotics which showed strong inhibition of reverse transcriptase were tested for their effects on the growth of murine lymphosarcoma L5178Y cells, selecting those suitable for the in vitro assay of the replication of AIDS-virus.

The details of assay method for reverse transcriptase and culture conditions for L5178Y cells were described previously ${ }^{11,14)}$. The re-

Table 1. Biological properties of peptide group antibiotics.

\begin{tabular}{|c|c|c|c|c|}
\hline \multirow{2}{*}{ Antibiotic } & \multicolumn{2}{|c|}{$\%$ Inhibition (RT) } & \multirow{2}{*}{$\begin{array}{c}\mathrm{ID}_{50}(\mu \mathrm{g} / \mathrm{ml}) \\
(\mathrm{L} 5178 \mathrm{Y})\end{array}$} & \multirow{2}{*}{$\begin{array}{l}\text { Applied to } \\
\text { HIV assay }\end{array}$} \\
\hline & $40 \mu \mathrm{g} / \mathrm{ml}$ & $10 \mu \mathrm{g} / \mathrm{ml}$ & & \\
\hline Actinomycin D & 6 & 0 & NT & No \\
\hline Janiemycin & 80 & 59 & $>4.0$ & Yes \\
\hline Colistin & 89 & 49 & $>4.0$ & Yes \\
\hline Enduracidin A & 67 & 50 & $>4.0$ & Yes \\
\hline Enduracidin B & 70 & 28 & $>4.0$ & Yes \\
\hline Luzopeptin A & 100 & 89 & 0.0003 & No \\
\hline Luzopeptin B & 96 & 97 & 0.016 & No \\
\hline Luzopeptin C & 100 & 100 & 0.8 & Yes \\
\hline Echinomycin & 11 & 0 & 0.003 & No \\
\hline Triostin A & 33 & 10 & NT & No \\
\hline
\end{tabular}

RT: Reverse transcriptase. NT: Not tested. 
Table 2. Biological properties of bleomycin group antibiotics.

\begin{tabular}{|c|c|c|c|c|}
\hline \multirow{2}{*}{ Antibiotic } & \multicolumn{2}{|c|}{$\%$ Inhibition (RT) } & \multirow{2}{*}{$\begin{array}{c}\mathrm{ID}_{50}(\mu \mathrm{g} / \mathrm{ml}) \\
(\mathrm{L} 5178 \mathrm{Y})\end{array}$} & \multirow{2}{*}{$\begin{array}{l}\text { Applied to } \\
\text { HIV assay }\end{array}$} \\
\hline & $40 \mu \mathrm{g} / \mathrm{ml}$ & $10 \mu \mathrm{g} / \mathrm{ml}$ & & \\
\hline Bleomycin $\mathrm{A}_{2}$ & 51 & 38 & 0.006 & No \\
\hline Bleomycin $\mathrm{B}_{2}$ & 23 & 12 & 0.005 & No \\
\hline Pepleomycin & 59 & 13 & 0.119 & No \\
\hline Platomycin A & 77 & 70 & 0.0009 & No \\
\hline Tallysomycin A & 63 & 31 & 0.028 & No \\
\hline
\end{tabular}

RT: Reverse transcriptase.

Fig. 1. Effects of luzopeptin C, janiemycin and colistin on the replication of HIV in MT-4 cells.

The cells infected with HIV were cultured in the presence of luzopeptin C, janiemycin or colistin at $37^{\circ} \mathrm{C}$ for 3 days. The viral antigen in methanol-fixed cells was stained by the indirect immunofluorescence method and the cell viability was measured by the trypan blue dye exclusion tes ${ }^{15}$.

(A) O Luzopeptin C, IF-positive cells; luzopeptin C, cell viability.

(B) O Janiemycin, IF-positive cells; janiemycin, cell viability; $\triangle$ colistin, IF-positive cells; colistin, cell viability.

(A)

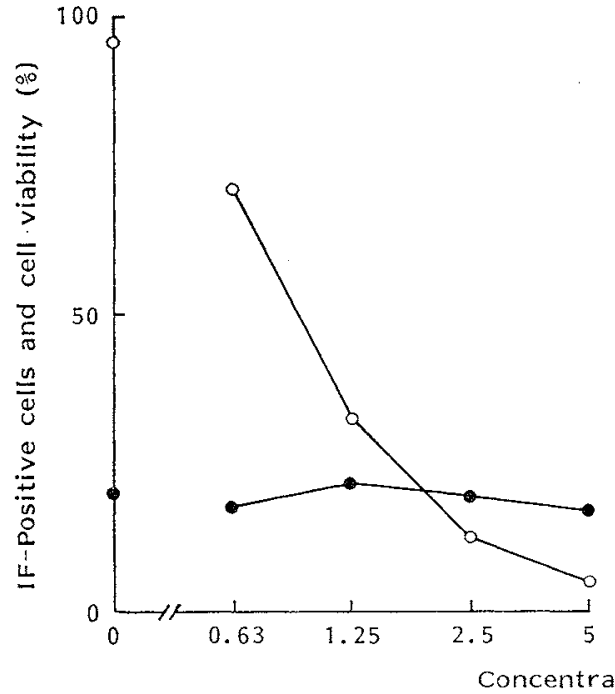

(B)

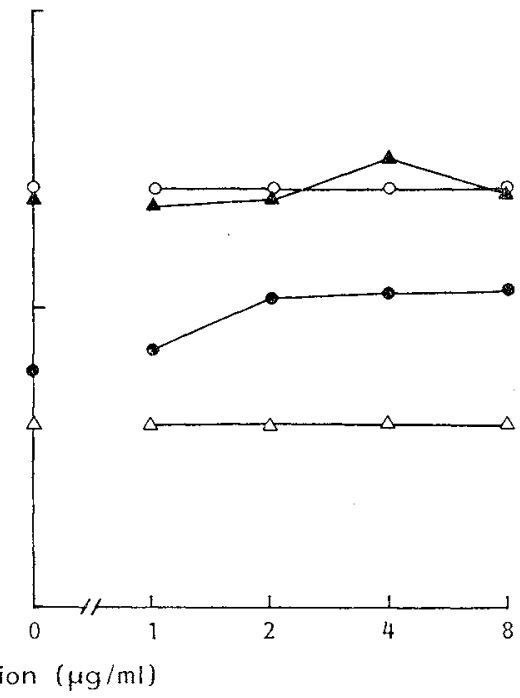

plication of AIDS-virus was assayed by the method of HARADA et al. ${ }^{15}$. Briefly, HIV HTLV-III was propagated in MT-4 cells in the presence of antibiotic and the expression of viral specific antigens was assayed 3 days after viral infection by the indirect immuno-fluorescence technique. The results shown in Tables 1 and 2 were presented as the percent inhibition of reverse transcriptase in the presence of either 40 or $10 \mu \mathrm{g} / \mathrm{ml}$ antibiotic and the concentration of each antibiotic giving $50 \%$ inhibition of cell growth. As a rule, the inhibition of reverse transcriptase over $70 \%$ at $40 \mu \mathrm{g} / \mathrm{ml}$ or $50 \%$ at $10 \mu \mathrm{g} / \mathrm{ml}$ was defined to be significant. When $\mathrm{ID}_{50}$ of the antibiotic selected by the enzyme assay against the growth of L5178Y cells was higher than $0.5 \mu \mathrm{g} / \mathrm{ml}$, it was applied to the in vitro viral assay. On the basis of these criteria, 15 antibiotics were selected out of 150 antibiotics tested. Further, sakyomicin $\mathrm{A}^{10)}$, adriamycin ${ }^{16)}$ and luzopeptin $\mathrm{C}$ (this paper) were finally proven to be effective against the replication of AIDSvirus. In this paper, the part of results obtained with the antibiotics classified in the peptide and bleomycin groups and the streptonigrin derivatives are described.

Though the inhibition of reverse transcriptase has not yet been reported by the peptide group 
Fig. 2. Effects of streptonigrin amide $\left(\mathrm{STN}-\mathrm{NH}_{2}\right)$ and the glycine derivative (STN-Gly) on the replication of HIV in MT-4 cells.

The cells infected with HIV were cultured in the presence of STN-NH2 (A) or STN-Gly (B) at $37^{\circ} \mathrm{C}$ for 3 days.

$O$ IF-positive cells, cell viability.

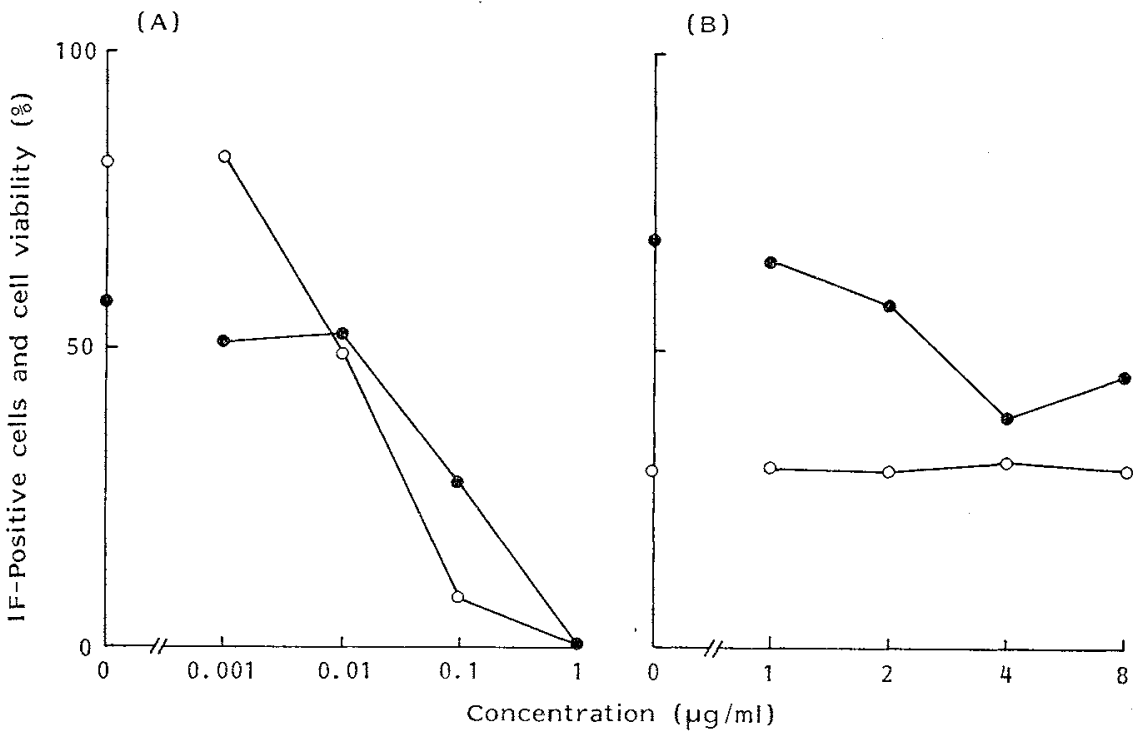

antibiotics with the exception of actinomycin $D^{17)}$, the strong inhibition of the enzyme was observed by janiemycin, colistin and enduracidins, and in particular by luzopeptins. Luzopeptins $\mathbf{A}$ and $\mathbf{B}$, bis and mono acetates of luzopeptin C, respectively, however, showed marked cytotoxicity against L5178Y cells in well accordance with the previous report ${ }^{18)}$. The results shown in Fig. 1A clearly demonstrate that the replication of $\mathrm{HIV}$ in $\mathrm{MT}-4$ cells is suppressed by luzopeptin $\mathrm{C}$ at higher concentrations $(2.5 \sim 5.0 \mu \mathrm{g} / \mathrm{ml})$, while the viability of MT-4 cells infected with HIV is not significantly affected in the same range of concentrations. In contrast, janiemycin and colistin lacked the ability to suppress the replication of HIV at concentrations up to $8 \mu \mathrm{g} / \mathrm{ml}$ (Fig. 1B) as well as enduracidins $\mathrm{A}$ and $\mathrm{B}$ (data not shown). The marked variation in the control values of $\%$ IF-positive cells is mainly due to the cytopathic effect of AIDS-virus and the difficulty in adjusting the rate of viral replication constant in the different experiments. In spite of the structural similarity to luzopeptins, the quinoxaline antibiotics, triostin $\mathrm{A}$ and echinomycin, were inactive against reverse transcriptase.
Reverse transcriptase was significantly inhibited by some of the bleomycin group antibiotics as exemplified by the results with platomycin $\mathrm{A}$, the antibiotics of this group gave such a profound damage to L5178Y cells that they were not applied to the AIDS system. In addition, no significant effect on the reverse transcriptase was observed by actinomycin $\mathrm{D}$ under the assay conditions employed in this work.

Streptonigrin (STN-OH) is one of the most potent inhibitors of reverse transcriptase among more than 150 antibiotics tested in our screening. Although the growth of L5178Y cells was tremendously suppressed by this antibiotic, we observed that the amide derivatives at the carboxyl group were far less toxic than STN$\mathrm{OH}$ without being accompanied by any marked decrease in inhibition of reverse transcriptase ${ }^{11}$. As examples, streptonigrin amide $\left(\mathrm{STN}-\mathrm{NH}_{2}\right)$ and the glycine derivative (STN-Gly) were tested for their effects on the replication of HIV, since both belonged to the compounds with marginal cytotoxicity. It is evident from the results shown in Fig. 2 that the inhibition of viral replication by $\mathrm{STN}-\mathrm{NH}_{2}$ is secondary to the decrease in cell viability and no significant 
effect on both viral replication and cell viability is observed by STN-Gly at concentrations up to $8 \mu \mathrm{g} / \mathrm{ml}$. We reported previously the marked defect of STN-Gly in membrane transport ${ }^{193}$ and this might account for the present observations.

\section{Acknowledgment}

This work was supported in part by a Grant-inAid for Cancer Research from the Ministry of Education, Science and Culture, Japan.

\section{References}

1) Temin, H. M.: The RNA tumor viruses -- background and foreground. Proc. Natl. Acad. Sci. U.S.A. 69: 1016 1020, 1972

2) Verma, I. M.: The reverse transcriptase. Biochim. Biophys. Acta 473: 1 38, 1977

3) Dalgleish, A. G.; P. C. L. Beverley, P. R. Clapham, D. H. Crawford, M. F. Greaves \& R. A. Weiss: The CD4(T4) antigen is an essential component of the receptor for the AIDS retrovirus. Nature 312: 763 767, 1984

4) Rozenbaum, W.; D. Dormont, B. Spire, E. Vilmer, M. GentilinI, C. Griscelli, L. MONTAGNIER, F. BARRE-Sinousst \& J.C. CHERMANN: Antimoniotungstate (HPA 23) treatment of three patients with AIDS and one with prodrome. Lancet 1985-I: 450 451, 1985

5) Broder, S.; R. Yarchoan, J. M. Collins, H. C. Lane, P. D. Markham, R. W. Klecker, R. R. Redfields, H. Mirsuya, D. F. Hoth, E. Gelmann, J. E. Groopman, L. Resnick, R. C. Galio, C. E. Myers \& A.S. Fauct: Effects of suramin on HTLV-III/LAV infection presenting as kaposi's sarcoma or AIDS-related complex: Clinical pharmacology and suppression of virus replication in vivo. Lancet 1985II: $627 \sim 630,1985$

6) YARCHOAN, R.; R.W. KLECKER, K.J. WEINHOLD, P. D. Markham, H. K. Lyerly, D. T. Durack, E. Gelmann, S. N. Lehrman, R. M. Blum, D. W. Barry, G. M. Shearer, M. A. Fischl, H. Mitsuya, R. C. Gallo, J. M. Collins, D. P. Bolognesi, C. E. Myers \& S. Broder: Administration of $3^{\prime}$-azido-3'-deoxythymidine, an inhibitor of HTLV-III/LAV replication, to patients with AIDS or AIDS-related complex. Lancet 1986-I: 575 580, 1986

7) GuRGo, C.; R. RAY \& M. GREeN: Rifamycin derivatives strongly inhibiting RNA-DNA polymerase (Reverse transcriptase) of murine sarcoma virus. J. Natl. Cancer Inst. 49: 61 79, 1972

8) Chandra, P.; F. Zunino, A. Götz, D. Gericke
\& A. Dimarco: Specific inhibition of DNA polymerases from RNA tumor viruses by some new daunomycin derivatives. FEBS Lett. 21: 264 268, 1972

9) Chandra, P.; F. Zunino, A. Götz, A. Wacker, D. Gericke, A. Dimarco, A. M. Cassazza \& F. Gruliani: Template specific inhibition of DNA polymerase from RNA tumor viruses by distamycin $\mathrm{A}$ and its structural analogues. FEBS Lett. 21: 154 158, 1972

10) Tanaka, N.; T. Okabe, N. Tanaka, Y. Take, Y. Inouye, S. Nakamura, H. Nakashima \& N. Yамамото: Inhibition by sakyomicin A of avian myeloblastosis virus reverse transcriptase and proliferation of AIDS-associated virus (HTLV-III/LAV). Jpn. J. Cancer Res. (Gann) 77: 324 326, 1986

11) Okada, H.; H. Mukai, Y. Inouye \& S. NakaMURA: Biological properties of streptonigrin derivatives. II. Inhibition of reverse transcriptase activity. J. Antibiotics 39: 306 308, 1986

12) Chirigos, M. A.; J. W. Pearson, J. S. Papas, W. A. Woods, H. B. WoOd, Jr. \& G. SpahN: Effect of streptonigrin (NSC-45383) and analogs on oncornavirus replication and DNA polymerase activity. Cancer Chemother. Rep. 57: 305 309, 1973

13) Toh, H.; H. Hayashida \& T. Miyata: Sequence bomology between retroviral reverse transcriptase and putative polymerases of hepatitis $\mathbf{B}$ virus and cauliflower mosaic virus. Nature 305: 827 829, 1983

14) INOUYE, Y.; H. ORaDA, S. K. RoY, T. MiYASaka, S. Hibino, N. TaNaKa \& S. Nakamura: Biological properties of streptonigrin derivatives. I. Antimicrobial and cytocidal activities. J. Antibiotics 38: 1429 1432, 1985

15) Harada, S.; Y. Koyanagi \& N. Yamamoto: Infection of human T-lymphotropic virus type-I (HTLV-I)-bearing MT-4 cells with HTLV-III (AIDS virus). Virology 14: 272 281, 1985

16) Nakashima, H.; N. Yamamoto, $Y$. INOUYE \& $S$. NAKAMURA: Inhibition by adriamycin of human immunodeficiency virus (HIV) infection and replication in vitro. J. Antibiotics 40(3): 1987 , in press

17) McDonnele, J. P.; A. Garapin, W. E. LeVinson, N. Quintrell, L. Fanshier \& J. M. Bishop: DNA polymerases of Rous sarcoma virus: Delineation of two reactions with actinomycin. Nature 228: 433 435, 1970

18) Ohkuma, H.; F. Sakal, Y. Nishiyama, M. Ohbayashi, H. Imanishi, M. Konishi, T. Miyaki, H. Koshiyama \& H. KaWaguchi: BBM-928, a new antitumor antibiotic complex. I. Production, isolation, characterization and antitumor activity. J. Antibiotics 33: 1087 
1097, 1980

19) InOUYe, Y.; H. Okada, J. Uno, T. Arai \& S.

NAKAMURA: Effects of streptonigrin deriva- tives and sakyomicin $\mathrm{A}$ on the respiration of isolated rat liver mitochondria. J. Antibiotics 39: $550 \sim 556,1986$ 